African Journal of Educational Studies in Mathematics and Sciences Vol. 16, No. 2, 2020

\title{
Effectiveness of Practical Work in Physics on Academic Performance among Learners at the selected secondary school in Rwanda
}

\author{
J. N. Twahirwa ${ }^{1} \&$ E. Twizeyimana ${ }^{2}$
}

\begin{abstract}
The current study investigates the effectiveness of practical work in physics on academic performance among learners of a secondary school in Rwanda. The study employs a quasi-experimental research design specifically pretest-posttest control group design (control group and experimental group). Two groups of learners of senior one at Groupe Scholaire Rugoma were treated differently through an expository and practice-based approach respectively. Physics achievement test prepared to evaluate the effect of practical work indicated that learners in the experimental group outperformed those of the control group treated by the expository teaching method. Various factors that may advance or hinder the implementation of practical work were identified and views from science teachers were collected. Most of the respondents strongly agreed that those factors have a significant impact on the implementation of practical work which in turn influence learners' overall academic performance during Physics Achievement Test (PAT). A significant difference was observed from the statistical analysis performed by using SPSS version 21.0. (Pretest and posttest among learners in the experimental group; $\mathrm{t}=27.243 ; 32.743 ; \mathrm{MD}=8.4239 ; 13.12500$ respectively whereas the pretest and posttest among learners are as follow, $\mathrm{t}=28.442$; $32.627 ; \mathrm{MD}=9.82500 ; 2.38005$ respectively and for all performance evaluation hypotheses were tested at .05 level of significance. Based on the observed results, it was found that practical work was more effective in improving learners' performance in Physics. It was therefore concluded that practical work continues to be a promising approach in teaching sciences, particularly teaching Physics in secondary schools.
\end{abstract}

Keywords physics achievement test; practice-based approach; control group; experimental group, practical work

\section{Introduction}

In the past decades, the dynamic nature of science has been significantly influenced by ever-increasing technology in the field of education. Practice-based education has been the trending research focus by investigators in teaching and learning advancement. Globally, countries have tremendously improved the way of instruction delivery in order to meet societal needs. Nowadays, practical work is at the forefront in teaching and learning endeavors. According to Eslinger, White, Frederiksen, and Brobst (2008); García-Carrión, Molina Roldán, and Roca Campos (2018), teaching and learning modalities that are believed to equip learners with practical skills in socalled learning by doing are have been

\footnotetext{
${ }^{1}$ Jean Nepomuscene Twahirwa, University of Rwanda-College of Education, African Center of Excellence for Innovative Teaching and Learning Mathematics and Science (ACEITLMS), P.O.Box 55, Rwamagana, Rwanda. Phone: +250789414285

2 Etienne Twizeyimana Chemistry teacher at Institut Paroissial de Mukarange, P.O.Box 36, Rwamagana, Rwanda, Phone: +250789622982, E-mail: etienne.twizeyimana@yahoo.com

Open Access article distributed under the terms of the Creative Commons Attributions License [CC BY-NC-ND 4.0] http://creativecommons.org/licenses/by-nc-nd/4.0. DOI: https://dx.doi.org/10.4314/ajesms.v16i.2.7
} 


\section{J. N. Twahirwal \& E. Twizeyimana ${ }^{2}$}

promising in knowledge and skill transfer. Learning by doing is far more advantageous in terms of knowledge and skills acquisition in any educational institution. The remarkable improvement in learning has been witnessed in an academic environment that allows interactive learning through inquiry processes as discussed in previous studies by Zittleman and Sadker (2015). Progressivism, social reconstructionism, and existentialism theories among others focused on training the mind through their own knowledge and skills acquisition, and these trending approaches have become the center of the educational processes. Recent studies in teaching and learning undertakings have greatly focused on learner-centered methodologies (Renzaho, Twizeyimana, Dufitumukiza, and Mujawimana, 2020); (Twizeyimana, Renzaho, and Mujawimana, 2020). Bringing learners' attention during classroom sessions requires much effort on the side of teachers and instructors. Obviously, the study conducted by Eddy, Converse, and Wenderoth (2015) emphasized that learners' participation can be taken to a higher level by feeling the sense of responsibility during grasping of their own knowledge and skills. Practical works fall among features that influence learning sciences in today's education. In its nature, practical work can be considered by scientists, particularly teachers as the core to the ultimatum and effectiveness of science education. According to Roberts (2002), it is highlighted that the quality of school science laboratories is of paramount importance, thus, acquiring skills in science and technology, engineering and mathematics needs a foundation in practical works. Teaching sciences, for instance, learning physics goes basically with students experiencing practical work as previously advanced by Sedumedi (2017). It has been argued that teaching using practical work in physics significantly increases the understanding of concepts by learners (Abou Faour and Ayoubi 2017); (Abrahams and Millar , 2008); Millar (2010). However, practice-based learning is rarely undertaken by most teachers in developing countries due to the scarcity of resources, inadequate practical skills, large class size in secondary schools, and inadequate infrastructures. In addition, teachers' attitudes to teaching physics through practice is critical based on the above-described factors. The teacherlearner interaction becomes meaningful when the teacher allows the learner to independently construct their own knowledge and skills, and in turn, the learner may need assistance from the teacher, thus, becoming a facilitator. Through the observation, critical analysis, and curiosity of learners, the sense of creativity is likely to be developed which in turn constitutes the fundamental of solid knowledge and skills. Moreover, learners are expected to discover and understand materials that are seemingly abstract to their perception.

\section{The Literature Review}

\section{Learning physics through practical work}

The past few decades have been characterized by changing from outdated traditional teaching modalities to modern teaching approaches. Teaching undertakings have been shifted from expository, teachercentered, to practice-based, learner-centered and the teacher serves as a facilitator. According to constructivism learning theory (Matthews, 1998) and social theory advanced by J Piaget (1955); Jean Piaget (1973), based on these theories, a learner is expected to shape how the knowledge and skills could be acquired thereby become the center of learning processes. Moreover, the learner's views about real life are taken into consideration. The core role of the teacher as 
African Journal of Educational Studies in Mathematics and Sciences Vol. 16, No. 2, 2020

the facilitator is to facilitate learners' engagement in their learning process with opportunities for exploration, discussion, think-pair-share, and problem-solving skills.

\section{Advantages of practical work in physics}

The practice-based teaching and learning approach is far more understood as a suitable approach to impart in learners long-lasting knowledge and skills (Bonnell et al., 2011). The widespread of technological tools coupled with vibrant discoveries and rapidly changing living styles due to high societal demand has concurrently pushed science educators to direct their teachings towards practical work, thus, allowing beneficiaries of knowledge and skills to gain practical skills that of course could be easily applied in a real-life situation. For instance, practical work in teaching and learning physics is accompanied by several advantages as it has been pointed out in many studies (Musasia, Abacha, and Biyoyo, 2012); Scanlon, Morris, Di Paolo, and Cooper (2002). Advantages of practical work include but are not limited to (1) imparting in learners longlasting life skills, (2) encourages selflearning, (3) promotes experiential learning, (4) discovering reality unrevealed in theories, (5) facilitating the implementation of concepts based on personal experience., etc. It is of utmost importance to embrace and implement the practice-based teaching and learning approaches due to their unparalleled advantages in teaching and learning endeavors.

\section{Constraints encountered by teachers in designing practical work}

Teachers are continually encountering several constraints in teaching and learning of sciences especially the scarcity of teaching and learning materials for some physics topics (Makori and Onderi, 2014); Uwizeyimana, Yadav, Musengimana, and Uwamahoro (2018). On the other side, some teachers lack a sense of creativity, self- confidence, and enough knowledge and skills for handling complex topics in physics (Orleans, 2007); Prince and Felder (2007). Worldwide, teaching sciences becomes meaningful when the content is delivered through stimulating methods. Inquiry-based learning is a trending method that is widely used to help learners acquire knowledge and skills in a long-lasting manner (Kim and Chin, 2011). However, strategies that are believed to facilitate the implementation of inquiry-based learning require suitable teaching and learning environment. For instance, practical activities have been problematic due to the lack of enough laboratory and demonstrating equipment, lack of qualified teachers, for this matter, most teachers in sub-Saharan countries do not have enough skills on computer use and therefore they are almost unable to enrich their lessons through a 3-D representation of the content. Moreover, in most schools, teaching and learning resources have been the focus of educators and researchers, though instruction delivery are still being dominated by teachers as the main source of knowledge and skills (Cess-Newsome, 1999); McMaster et al. (2020) . There is still an urgent of shifting from traditional teaching modalities to modern teaching ones. Notwithstanding the effort that is being made for embracing helpful and learner-centered approaches aligned with the ever-increasing demand for skilled manpower. Therefore, the race is far more competitive. Teachers as workforce and education stakeholders are key pillars towards successful implementation.

\section{Attitudes of learners during practical work}

One of the factors that capture learners' attention during the learning process is the design of instructional materials able to integrate attitudes (Baartman and De Bruijn, 2011); Yang and Tsai (2010), perception and motivation of every individual learner present in the classroom (Ames and Archer, 
1988); Church, Elliot, and Gable (2001); Meyer and Turner (2002); Van Heuvelen (1991). It is imperative that observers easily track the attitudes of learners in science education, and according to previous studies, some learners in secondary schools have a negative attitude towards physics with discouraging behaviors during classroom sessions. Despite the drawbacks that have been indicated by previous studies, there are other learners who courageously follow physics education thereby demonstrating a sense of curiosity and exploration of the facts. Such kinds of learners have eager to know more with highclass engagement. According to (Craker (2006), attitudes towards science vary with exposure to science concept, but the direction of change may be related to the quality of that exposure that is the learning environment, and the teaching method. Attitude is comprised of two component parts which are effective in dealing with the mental processes (George, 2000). This can be explained as a result of inadequate infrastructure and the necessary equipment to carry out the required experimental studies. Physics is considered the most problematic area within the realm of science, and it traditionally attracts fewer students than chemistry and biology (Olusola and Rotimi, 2012); Sharpe and Abrahams (2020).

A

Learners' Engagement in Continuous Learning (LECL)

Skilled facilitators (SL)

School Infrastructures (SI)

Motivating Academic Community within the School Settings (MAC2S)

A: Independent variables

B \& C: Dependent variables

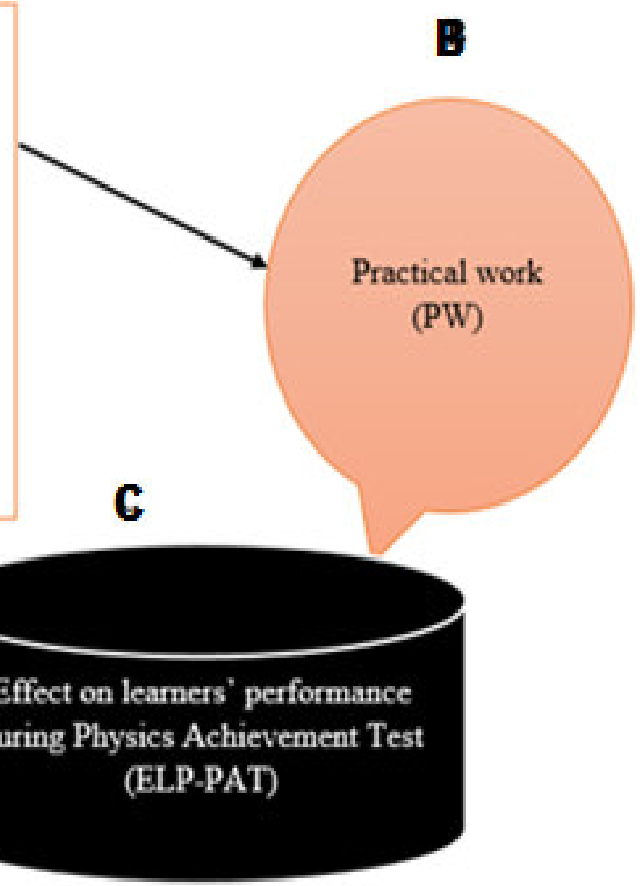

Effect on learners' performance during Physics Achievement Test (ELP.PAT)

Figure 1 Guiding research model 
African Journal of Educational Studies in Mathematics and Sciences Vol. 16, No. 2, 2020

\section{The research objectives and questions}

Based on the above literature review, the study was planned to systematically identify factors that can affect learners' understanding of physics and to show how practical work can improve learners' understanding of physics. To achieve these objectives, the following questions were formulated to guide the study:

1. What are the factors that affect learners' understanding of the content in physics?

2. To what extent does practical work improve learners' understandings of physics?

To answer the second research question, the following null and alternative hypotheses were formulated to investigate the impact of practical work on learners' academic performance.

Ho1: There exists a significant difference among senior one learners when they are taught through the practice-based approach

$\mathrm{Ho}_{2}$ : There exists no significant difference among senior one learners when they are taught through an expository teaching approach

\section{Research Methodology}

The current study was conducted to examine the effectiveness of practical work in physics on academic performance among learners of senior one at the selected secondary school in Rwanda. In this part, all procedures involved are described.

\section{Research design, methods and research tools}

The study employed a quasi-experimental research design specifically pretest-posttest control group design. The current study started with observation as a promising way forward to identifying the existing problem of poor performance in physics and related hindrances within an academic environment. Thereafter, both formative and summative evaluation of learners were given priority during data collection in the so-called pretest and posttest non-randomized control and experimental group. Apart from tests given to learners, a questionnaire was designed and sent to 20 selected science teachers to gain their insight into practical work and hindrances towards successful implementation. A telephone interview was conducted for both teachers and the director of studies for a better understanding of the questions that were under investigation.

Data collection procedures, Data analysis and presentation

Learners from two classes of senior one were considered first and purposively distributed into two groups namely the control group and experimental group. Both groups were taught the topic adapted from the Rwandan national curriculum "rectilinear propagation of light" by different teaching approaches. Intentionally, learners in the experimental group were given an instruction through a practice-based approach while learners in the control group were given instruction through an expository teaching approach. The research was conducted to comprise dependent and independent variables, as well as extraneous variables that were investigated through questionnaires given to sciences teachers. We wanted to evaluate the effectiveness of practical work in teaching and learning of physics, therefore, teaching approaches were deliberated as independent variables, and learners learning attitudes and performance were deliberated as dependent variables. A pretest was administered to both groups as a graded assessment tool to determine the preliminary knowledge and skills before applying different teaching approaches. Thereafter, an expository 


\section{J. N. Twahirwal \& E. Twizeyimana ${ }^{2}$}

teaching approach and practice-based approach were respectively applied to the control and experimental group. In all circumstances, the measurement of performance was conducted to measure the extent to which teaching methods influenced the learning attitudes and performance in physics

\begin{tabular}{lll} 
Table 1 & $\begin{array}{l}\text { Topics of Specific Lessons planned and Teaching and Learning Materials } \\
\text { used for the experimental group in each unit of the topic Rectilinear } \\
\text { Propagation of Light }\end{array}$ \\
\hline Unit & Specific Lesson Topic & Teaching and learning materials \\
\hline Unit 1 & Different sources of light & $\begin{array}{l}\text { Fireflies, candle, fire, sun, electric bulb, } \\
\text { earth and moon, electric bulb and even } \\
\text { resources which may help in making fires }\end{array}$ \\
Unit 2 & Rays and beams & $\begin{array}{l}\text { Concave lens, convex lens, hammer, dark } \\
\text { room, nail, and even cardboard, torch as a } \\
\text { source of light. }\end{array}$ \\
Unit 3 & $\begin{array}{l}\text { Classification of materials } \\
\text { as transparent, translucent } \\
\text { and opaque }\end{array}$ & $\begin{array}{l}\text { Clear glasses, ailed paper, water as well as } \\
\text { air, frosted glass, rocks, and metals. }\end{array}$ \\
Unit 4 & $\begin{array}{l}\text { Rectilinear propagation of } \\
\text { light }\end{array}$ & $\begin{array}{l}\text { Three hard papers, Table, A nail, thread, } \\
\text { candle; Matches }\end{array}$ \\
Unit 5 & $\begin{array}{l}\text { Formation of shadows } \\
\text { and eclipses } \\
\text { Types of reflection }\end{array}$ & $\begin{array}{l}\text { Big ball, Small ball, Torch } \\
\text { Unit 6 }\end{array}$ \\
\hline
\end{tabular}

Table 1 shows the topics of specific lessons planned and teaching and learning materials used for the experimental group in each unit of the topic rectilinear propagation of light. Was the order followed by the control group and which materials did the control group use. Data analysis was performed by using SPSS version 21.0. The generated statistical results were presented by using histograms and tables.

\section{Results and discussion}

The current study was conducted to investigate the effectiveness of practical work on learners' performance in physics achievement test (PAT). We intentionally distributed learners of senior one into two groups namely the control and experimental group, thereafter, these groups were treated differently during teaching and learning activities. As clearly detailed in the previous sections, it is hypothesized that within an academic environment various factors such as the extent to which learners engage in continuous learning, the availability or the absence of skilled facilitators, the nature of infrastructures, and the academic community mighty have an influence on conducting practical work smoothly within schools. On the other hand, practical work 
African Journal of Educational Studies in Mathematics and Sciences Vol. 16, No. 2, 2020

when conducted smoothly they can positively affect the overall learners' academic performance (Figure 2). It is on this basis that the present study was conducted. As presented in Figures 3 and 4, various factors were identified as having a potential influence on learners' overall skilled facilitators are core part teaching and learning endeavors); School infrastructures were seen as of paramount importance within an academic environment, even though $15 \%$ of respondents remained neutral, about $85 \%$ of all respondents emphasized that school infrastructures plays

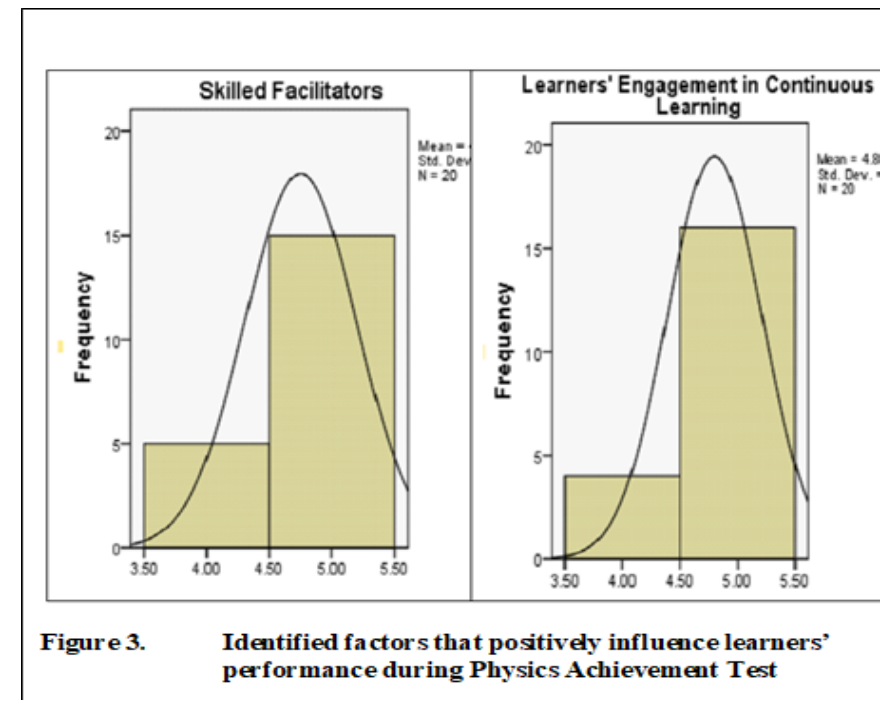

academic performance; the following are the identified factors: Learners engagement in continuous learning (20\%; agree, $80 \%$; Strongly agree); Skilled facilitators (25\% of the total respondents agreed that skilled facilitators are a factor towards successful implementation practical work in physics while $75 \%$ Strongly agreed on the fact that

an important role in practical works. All respondents asserted that motivating academic community within the school setting is positively aligned with practical work implementation. In this view, 30\% agreed and $70 \%$ strongly agreed that motivating academic environment can greatly influence the application of the

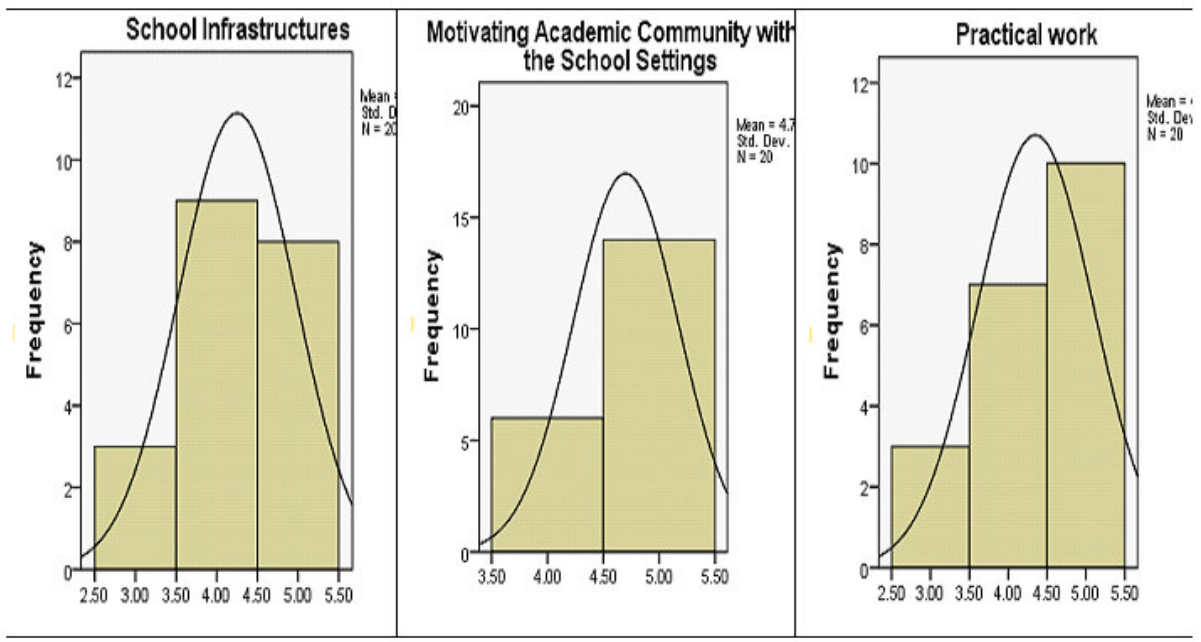

Figure 4

Identified factors that positively influence learners' performance during Physics Achievement Test 


\section{J. N. Twahirwal \& E. Twizeyimana ${ }^{2}$}

practical work. Of the total respondents, $85 \%$ of respondents asserted that practical work positively affect learners'

It is noted that most of the research participants strongly agreed that all of the identified factors could influence the practical work and in turn, the practical work can greatly influence learners' smooth learning of physics. Apart from effects exerted by these factors on smooth learning
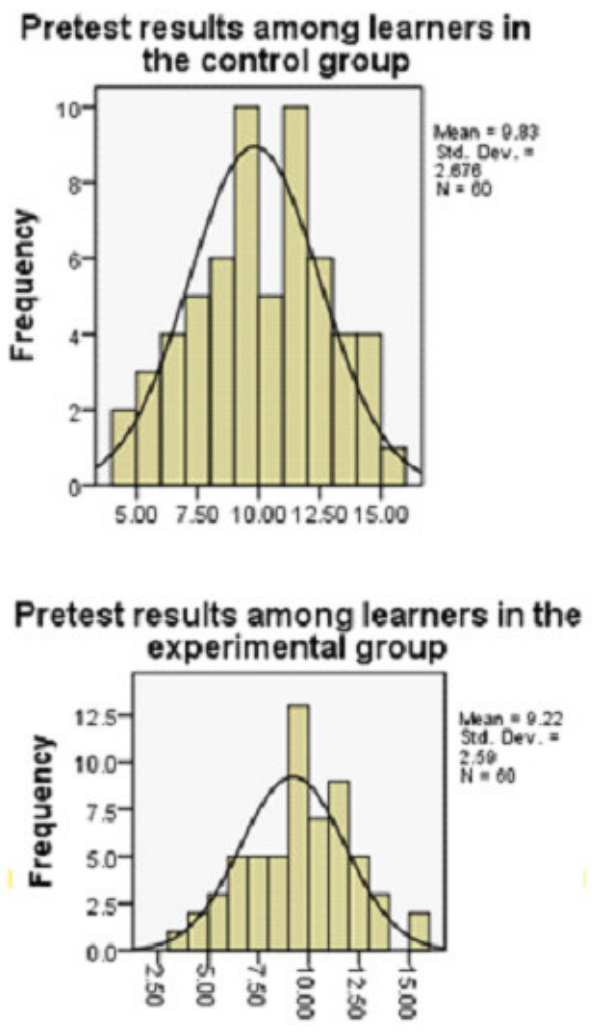

of physics among learners of senior one, the topic entitled "rectilinear propagation of light" was delivered to the experimental group differently to the control group, as neatly presented in Figure 5, learners of the experimental group outperformed those of control group after being treated by different teaching approach. The treatment of the experimental group utilized different experimental equipment (Table 1).
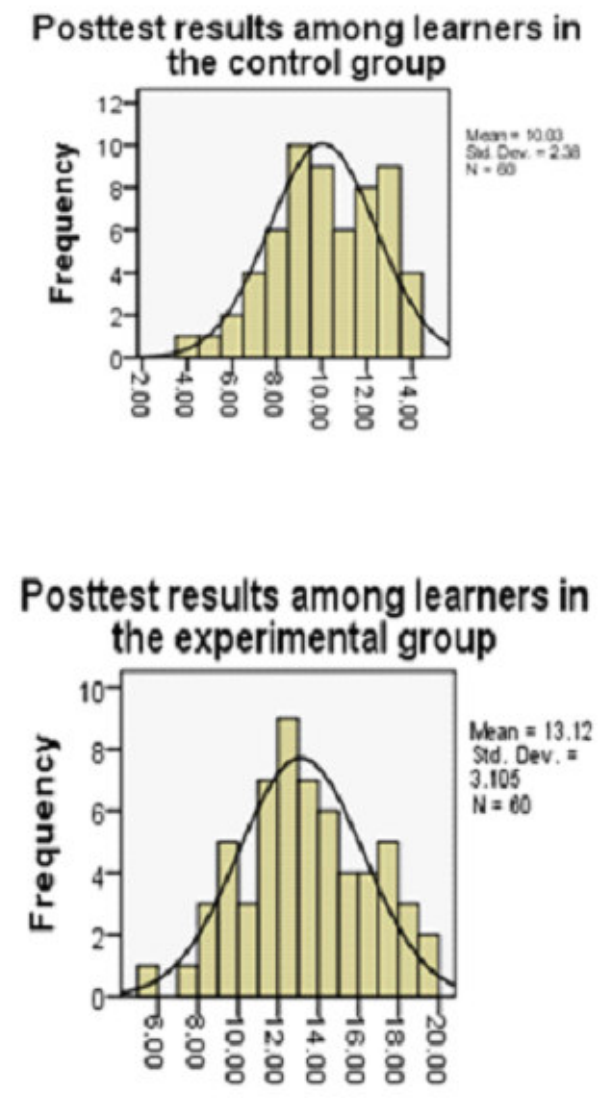

Figure 5 Frequency histograms for study participants in control and experimental group

The first hypothesis was "there exists a significant difference among senior one learners when they are taught through the practice-based approach" and the second one "there exists no significant difference among senior one learners when they are taught through expository teaching approach". And all hypotheses were proven respectively and for all performance evaluation hypotheses were tested at .05 level of significance as indicated in Table 2. Based on the above results, it is seen that practical work was effective in improving learners' performance during Physics Achievement Test (PAT). 
African Journal of Educational Studies in Mathematics and Sciences Vol. 16, No. 2, 2020

Table 2 Independent t-test results of control and experimental group before and after the treatment

\begin{tabular}{lcccccc}
\hline & $\mathrm{N}$ & $\mathrm{M}$ & $\mathrm{S} . \mathrm{D}$. & $\mathrm{t}$ & $\mathrm{df}$ & Sig. (2-tailed) \\
\hline Pretest control group & 60 & 9.83 & 2.68 & 28.442 & 59 & .000 \\
Posttest control group & 60 & 10.03 & 2.38 & 32.672 & 59 & .000 \\
Pretest experimental group & 60 & 8.42 & 2.59 & 27.243 & 59 & .000 \\
Posttest experimental group & 60 & 13.13 & 3.10 & 32.743 & 59 & .000 \\
\hline
\end{tabular}

\section{Conclusion and future perspectives}

Creativity and innovation are key factors that are believed to significantly contribute to scientific advancement. Teaching sciences in secondary schools requires creativity, innovation, critical thinking, and the ability to enrich instruction through designing teachings that allow learnerinstruction-teacher interaction. In this study, various factors that could hinder the implementation of a practice-based approach have been identified, and most of the research participants strongly asserted that learners engagement in continuous learning, skilled facilitators, school infrastructures, motivating academic community within the school setting, and practical work influence learning activities through a practice-based approach. We neatly explained the effectiveness of practical work among senior one learners, and it is clear that this approach is effective for improving learners' overall academic performance during Physics Achievement Test. This study has been limited to selected secondary schools in Rwanda, therefore, other researchers are encouraged to extend the related investigations in their academic environment. Moreover, teachers and school leaders are recommended to work hand in hand to successfully design and implement a practice-based approach.

\section{Acknowledgement}

We thankfully acknowledge the financial support from the University of RwandaCollege of Education, particularly, the African Center of Excellence for Innovative Teaching and Learning Mathematics and Science (ACEITLMS). We also thankfully acknowledge the collaboration and good cooperation with Mr. Kizito Ndihokubwayo and Fidele Ukobizaba from ACEITLMS

\section{References}

Abou Faour, M., \& Ayoubi, Z. (2017). The effect of using virtual laboratory on grade 10 students' conceptual understanding and their attitudes towards physics. Journal Of Education In Science Environment And HEALTH, 4(1), 54-68.

Abrahams, I., \& Millar, R. (2008). Does practical work really work? A study of the effectiveness of practical work as a teaching and learning method in school science. International journal of science education, 30(14), 19451969. 
Effectiveness of Practical Work in Physics on Academic Performance among Learners at the Selected Secondary School in Rwanda

\section{J. N. Twahirwa ${ }^{1}$ \& E. Twizeyimana ${ }^{2}$}

Ames, C., \& Archer, J. (1988). Achievement goals in the classroom: Students' learning strategies and motivation processes. Journal of educational psychology, 80(3), 260.

Baartman, L. K., \& De Bruijn, E. (2011). Integrating knowledge, skills and attitudes: Conceptualising learning processes towards vocational competence. Educational Research Review, 6(2), 125-134.

Bonnell, J., Copestake, P., Kerr, D., Passy, R., Reed, C., Salter, R., ... Sheikh, S. (2011). Teaching approaches that help to build resilience to extremism among young people. Department for Education (DFE): Research Report DFE-RR119.

Cess-Newsome, J. (1999). Secondary teachers' knowledge and beliefs about subject matter and their impact on instruction Examining pedagogical content knowledge (pp. 51-94): Springer.

Church, M. A., Elliot, A. J., \& Gable, S. L. (2001). Perceptions of classroom environment, achievement goals, and achievement outcomes. Journal of educational psychology, 93(1), 43.

Craker, D. E. (2006). Attitudes toward science of students enrolled in introductory level science courses at UW-La Crosse. UW-L Journal of undergraduate research IX, 9, 1-6.

Eddy, S. L., Converse, M., \& Wenderoth, M. P. (2015). PORTAAL: A classroom observation tool assessing evidencebased teaching practices for active learning in large science, technology, engineering, and mathematics classes. CBE-Life Sciences Education, 14(2), ar23.
Eslinger, E., White, B., Frederiksen, J., \& Brobst, J. (2008). Supporting inquiry processes with an interactive learning environment: Inquiry Island. Journal of Science Education and Technology, 17(6), 610-617.

García-Carrión, R., Molina Roldán, S., \& Roca Campos, E. (2018). Interactive learning environments for the educational improvement of students with disabilities in special schools. Frontiers in psychology, 9, 1744.

George, R. (2000). Measuring change in students' attitudes toward science over time: An application of latent variable growth modeling. Journal of Science Education and Technology, 9(3), 213-225.

Kim, M., \& Chin, C. (2011). Pre-Service Teachers' Views on Practical Work with Inquiry Orientation in Textbook-Oriented Science Classrooms. International Journal of Environmental and Science Education, 6(1), 23-37.

Makori, A., \& Onderi, H. (2014). Examining the teaching and learning resources related challenges facing small and medium-sized public secondary schools in Kenya: A comparative analysis.

Matthews, M. R. (1998). Constructivism in science education: A philosophical examination: Springer Science \& Business Media.

McMaster, K. L., Lembke, E. S., Shin, J., Poch, A. L., Smith, R. A., Jung, P.G., . . . Wagner, K. (2020). Supporting teachers' use of databased instruction to improve students' early writing skills. Journal of educational psychology, 112(1), 1. 
African Journal of Educational Studies in Mathematics and Sciences Vol. 16, No. 2, 2020

Meyer, D. K., \& Turner, J. C. (2002). Discovering emotion in classroom motivation research. Educational psychologist, 37(2), 107-114.

Millar, R. (2010). Practical work. Good practice in science teaching: What research has to say, 108-134.

Musasia, A. M., Abacha, O. A., \& Biyoyo, M. E. (2012). Effect of Practical Work in Physics on Girls' Performance, Attitude change and Skills acquisition in the form twoform three Secondary Schools' transition in Kenya. International Journal of Humanities and Social Science, 2(23), 151-166.

Olusola, O. O., \& Rotimi, C. (2012). Attitudes of students towards the study of physics in College of Education Ikere Ekiti, Ekiti State, Nigeria. American International Journal of Contemporary Research, 2(12), 86-89.

Orleans, A. V. (2007). The condition of secondary school physics education in the Philippines: Recent developments and remaining challenges for substantive improvements. The Australian educational researcher, 34(1), 33-54.

Piaget, J. (1955). The Construction of Reality in the Child (Vol. 82). Abingdon: United Kingdom: Routledge.

Piaget, J. (1973). Psychology and epistemology.

Prince, M., \& Felder, R. (2007). The many faces of inductive teaching and learning. Journal of college science teaching, 36(5), 14.

Renzaho, a., Twizeyimana, e., Dufitumukiza, b., \& Mujawimana, e. (2020). Cooperative learning approach: a learner-centered methodology for alleviating the nonrepresentational nature of science education among learners of secondary schools in rwanda. Journal of Global Research in Education and Social Science, 14(2), 45-56.

Roberts, S. G. (2002). SET for success: The supply of people with science, technology, engineering and mathematics skills: HM Treasury London.

Scanlon, E., Morris, E., Di Paolo, T., \& Cooper, M. (2002). Contemporary approaches to learning science: technologically-mediated practical work.

Sedumedi, T. D. T. (2017). Practical work activities as a method of assessing learning in chemistry teaching. Eurasia Journal of Mathematics, Science and Technology Education, 13(6), 1765-1784.

Sharpe, R., \& Abrahams, I. (2020). Secondary school students' attitudes to practical work in biology, chemistry and physics in England. Research in Science \& Technological Education, 38(1), 84104.

Twizeyimana, E., Renzaho, A., \& Mujawimana, E. (2020). Effectiveness of locally made instructional materials on students academic performance and retention in science education in eastern province of Rwanda. International Journal Of All Research Writings, 1(11), 29-37.

Uwizeyimana, D., Yadav, L., Musengimana, T., \& Uwamahoro, J. (2018). The impact of teaching approaches on effective physics learning: an 
Effectiveness of Practical Work in Physics on Academic Performance among Learners at the Selected Secondary School in Rwanda

J. N. Twahirwal \& E. Twizeyimana ${ }^{2}$

investigation conducted in five Secondary Schools in Rusizi District, Rwanda. Rwandan Journal of Education, 4(2), 4-14.

Van Heuvelen, A. (1991). Learning to think like a physicist: A review of research-based instructional strategies. American Journal of physics, 59(10), 891-897.

Yang, D. C., \& Tsai, Y. F. (2010). Promoting sixth graders' number sense and learning attitudes via technology-based environment. Journal of Educational Technology \& Society, 13(4), 112-125.

Zittleman, K., \& Sadker, D. M. (2015). Teachers, schools, and society: a brief introduction to education: McGraw-Hill Higher Education. 
African Journal of Educational Studies in Mathematics and Sciences Vol. 16, No. 2, 2020 